\title{
AUDIT INTERNAL UNIVERSITAS X: SUATU REFLEKSI
}

\author{
David Adechandra Ashedica Pesudo \\ Fakultas Ekonomika dan Bisnis, Universitas Kristen Satya Wacana \\ david.pesudo@staff.uksw.edu \\ Marwata \\ Fakultas Ekonomika dan Bisnis, Universitas Kristen Satya Wacana \\ marwata@staff.uksw.edu \\ Gustin Tanggulungan \\ Fakultas Ekonomika dan Bisnis, Universitas Kristen Satya Wacana \\ gustin@staff.uksw.edu
}

\begin{abstract}
The purpose of this study is to provide empirical evidence on the dynamics of the operation of internal audit function at a private university by describing various factors that influence the operation of internal audit function in universities. More specifically, this study describes the conditions of various factors that influence the effectiveness of internal audit function in nonprofit organizations identified by (Ahmad et al., (2009) in a specific organizational context of a private university. We use a qualitative case study approach as our research strategy and analysis. We generate our research data by conducting in-depth interviews with various informants who have sufficient information on the internal audit activities at our case. Our study shows that the dynamics of the operation of internal audit function is affected by various supporting factors, namely the number of internal audit staff, cooperation from auditee, competencel knowledge of audit techniques, follow-up actions of audit findings, recommendations of auditees/ management, and audit experience. We also identify some factors that do not support the dynamics of the operation of internal audit function, namely top management commitment, training, independence, organizational changes in the internal audit division, auditees' perception on internal audit function, and human resources.
\end{abstract}

Keywords: internal audit, internal audit activity, university, nonprofit organization.

\begin{abstract}
ABSTRAK
Penelitian ini bertujuan untuk menyediakan bukti empiris tentang dinamika beroperasinya fungsi audit internal dalam sebuah universitas swasta dengan mendeskripsikan berbagai faktor yang mempengaruhi keefektifan fungsi audit internal di sebuah universitas. Secara khusus, studi ini mendeskripsikan kondisi berbagai faktor yang mempengaruhi keefektifan fungsi audit internal dalam organisasi nirlaba yang diidentifikasi oleh Ahmad et al., (2009) dalam suatu konteks organisasi sebuah universitas swasta. Studi ini menggunakan strategi penelitian studi kasus dengan menggunakan pendekatan kualitatif untuk menganalisis data. Wawancara mendalam dengan berbagai pihak yang memiliki pengetahuan tentang
\end{abstract}


kegiatan audit internal di universitas yang menjadi studi kasus menjadi sumber utama data untuk studi ini. Penelitian ini menunjukkan bahwa dinamika beroperasinya fungsi audit internal universitas swasta yang menjadi studi kasus dipengaruhi oleh berbagai faktor. Beroperasinya fungsi audit internal di organisasi dipengaruhi oleh sejumlah faktor yang bersifat mendukung yaitu jumlah staf audit internal, kerjasama dari auditee, kompetensi/pengetahuan tentang teknik audit, tindakan pada temuan audit dan rekomendasi oleh auditee/manajemen, dan pengalaman audit. Sementara itu, sejumlah faktor bersifat tidak mendukung bagi beroperasinya fungsi audit internal, yaitu komitmen dari manajemen puncak, pelatihan, independensi, perubahan dalam organisasi divisi audit internal, persepsi dari auditee terhadap fungsi audit internal, dan sumber daya.

Kata kunci: audit internal, aktivitas audit internal, universitas swasta, organisasi nirlaba.

\section{PENDAHULUAN}

Tuntutan universitas untuk memiliki tata kelola organisasi yang baik atau tata pamong yang berkualitas menjadi bagian penilaian borang akreditasi Badan Akreditasi Nasional Perguruan Tinggi Indonesia. Universitas di Australia pada dua dekade terakhir juga mengalami pergeseran dari organisasi publik dana manajerial kolegial menjadi new public management, market public administration dan corporate managerialism (Eckel \& Kezar 2006; Parker 2011). Universitas saat ini harus dapat menerapkan konsep Good University Governance (GUG), dimana suatu institusi pendidikan tinggi harus dapat mengelola organisasi mengarah kepada tujuannya. Institusi Pendidikan tinggi juga mengalami berbagai perubahan model pengelolaan menuju kepada New Public Management, yang menekankan pada penilaian kerja yang kuat, monitoring, dan sistem manajemen, dengan didukung oleh tumbuhnya sistem audit (Ferlie \& Ongaro 2015).

Selanjutnya berkaitan dengan meningkatnya kegiatan perekonomian, baik dalam skala maupun dalam jenis, menyebabkan risiko yang meningkat pada setiap entitas bisnis, tidak terkecuali lembaga pendidikan tinggi, dan hal ini dapat mengancam proses pencapaian tujuan. Bertambahnya risiko di dalam mencapai tujuan-tujuan organisasi tersebut menyebabkan setiap lembaga pada akhirnya harus melakukan pembenahan diri dan peningkatan kinerja (Vijayakumar \& Nagaraja 2012). Kebutuhan akan adanya perbaikan yang berkelanjutan pada setiap organisasi dan lembaga memunculkan kebutuhan akan mekanisme kontrol. Audit internal merupakan mekanisme kontrol yang tidak dapat dilepaskan untuk menuju ke arah Good Governance (Cohen \& Sayag 2010; Florea 2013).

Perkembangan penerapan fungsi audit internal pada organisasi telah berlangsung dengan sangat cepat di dunia. Fungsi audit internal yang awalnya hanya berfokus pada fraud, terutama pencurian kas dan aset lainnya sekarang telah berkembang menjadi suatu sarana verifikasi terhadap seluruh transaksi finansial yang 
dilakukan oleh organisasi. Pendekatan yang dilakukan dalam audit internal pun mengalami beberapa evolusi. Pertama, audit internal tidak lagi hanya berupa penilaian mengenai kepatuhan dan aktivitas karyawan, namun menjadi suatu fungsi pemeriksaan independen operasional yang memiliki skopa yang luas dalam segala aktivitas perusahaan (Moeller 2009). Kedua, pergeseran yang awalnya hanya menjadi "pengawas" yang memberikan assurance kepada para stakeholders, sekarang juga merangkap sebagai consulting agent, yang bertujuan untuk menambah nilai perusahaan (Anderson 2003). Perkembangan audit internal yang cepat ini juga tak bisa lepas dari tuntutan para stakeholders suatu organisasi yang menginginkan adanya peningkatan kinerja, transparansi, dan akuntabilitas (Ahmad et al., 2009).

Penelitian pada fungsi audit internal mulai bermunculan seiring dengan perkembangan fungsi audit internal. Penelitian mengenai efektivitas internal audit lebih banyak dilakukan pada ranah organisasi privat yang merupakan profit-oriented organizations. Selain penelitian di sektor privat, penelitian yang telah dilakukan terkait dengan audit internal pada lembaga publik. Penelitian Ahmad et al. (2009) yang dilakukan pada lembaga publik di Malaysia, yaitu pada dinas-dinas pemerintahan, baik pusat maupun daerah, memperlihatkan adanya faktor-faktor yang menghambat audit internal pada lembaga publik, baik faktor-faktor personal maupun organisasional. Penelitian tersebut memberikan pengetahuan tentang berbagai macam faktor yang dapat mempengaruhi fungsi internal audit pada lembaga publik tersebut. Namun penelitian tersebut belum menjelaskan bagaimana faktor-faktor itu berdampak pada fungsi audit internal dalam suatu lingkungan organisasi publik yang spesifik. Oleh karena itu, perlu dilakukan riset untuk mengeksplorasi bagaimana faktor-faktor tersebut mempengaruhi fungsi audit internal dalam lingkungan organisasi publik yang spesifik.

Melihat minimnya literatur yang terkait dengan audit internal pada lembaga publik terkhusus universitas, dapat dipahami bahwa universitas, sebagai lembaga publik dan non profit, selama ini belum menjadi kajian para peneliti fenomena audit internal, terutama di Indonesia. Dengan adanya penelitian ini diharapkan literatur audit internal pada lembaga publik yang khusus dapat diperkaya.

Penelitian ini menganalisis faktor-faktor yang mempengaruhi fungsi audit internal di Universitas X pada periode 2013. Selain itu penelitian ini juga bertujuan untuk merancang upaya untuk meningkatkan kinerja fungsi audit internal di Universitas $\mathrm{X}$ yang merupakan sebuah institusi pendidikan yang berusia lebih dari 50 tahun dan operasionalnya fungsi audit internal di dalamnya mengalami dinamika.

Penelitian ini merupakan suatu riset yang memiliki kontribusi bagi Universitas X untuk mendapat informasi faktor-faktor yang mempengaruhi fungsi audit internal dan meningkatkan kinerja unit tersebut. Dari aspek teoritis, riset ini memberi hasil telaah yang menjelaskan konsep fungsi audit internal dalam praktik pengelolaan perguruan tinggi 


\section{KAJIAN PUSTAKA DAN PERUMUSAN HIPOTESIS}

\section{Audit Internal sebagai Salah Satu Instrumen Manajemen Risiko Organisasi}

Suatu organisasi dibentuk berdasarkan tujuan-tujuan tertentu. Organisasi publik dibentuk dengan tujuan untuk melayani kepentingan dan kebutuhan publik (Mahsun et al., 2007). Jadi tujuan-tujuan yang harus dicapai oleh suatu organisasi publik secara umum adalah mensejahterakan masyarakat melalui berbagai cara. Universitas sebagai suatu lembaga publik, di dalam menetapkan rencana stratejik, dan rencana operasional juga memperhatikan kesejahteraan masyarakat luas, hal ini terkait universitas sebagai lembaga publik yang bertujuan melayani masyarakat luas.

Untuk dapat memberikan pelayanan yang terbaik kepada masyarakat, tanpa mengorbankan kepentingan organisasi dan termasuk pihak-pihak internal, universitas seharusnya melakukan perbaikan dan pembenahan secara internal. Melihat perkembangan ekonomi, bisnis, dan akuntansi saat ini yang sangat terkait dengan perbaikan tersebut, universitas sebagai suatu lembaga keilmuan seharusnya mulai menerapkan suatu fungsi audit internal di dalam menilai kinerja internalnya terutama audit internal finansial. Selain hal tersebut, menurut (Vijayakumar \& Nagaraja 2012) audit internal telah menjadi alat yang paling sering digunakan di dalam mengendalikan risiko di dalam lembaga-lembaga publik. Lebih lanjut dijelaskan bahwa audit internal merupakan alat yang efektif di dalam pengendalian risiko operasional, finansial, hukum, dan peraturan.

Selanjutnya isu mengenai globalisasi, transparansi, integritas, dan peningkatan kinerja dan layanan dari lembaga publik, meningkatkan kebutuhan akan pengelolaan yang baik dan akuntabilitas. Fenomena ini yang membuat ketertarikan kepada audit internal di dalam organisasi, terutama organisasi publik meningkat (Ahmad et al., 2009).

Selain di dalam perannya sebagai suatu lembaga publik, universitas juga termasuk di dalam kumpulan lembaga atau entitas bisnis, meskipun universitas tidak termasuk ke dalam suatu entitas yang profit oriented. Dalam kaitannya universitas sebagai entitas bisnis, para stakeholder menuntut agar universitas tetap memiliki semangat kompetitif diantara universitas lainnya (Willson et al., 2010). Universitas diharapkan memiliki suatu fungsi audit internal yang baik agar tetap memiliki daya saing di tengah perubahan ekonomi yang dinamis pada saat ini. Perubahan yang cepat dalam perekonomian, segi finansial, dan tiap hal yang terkait menyebabkan universitas sebagai entitas bisnis akan menemukan tantangan baru, yang diikuti meningkatnya risiko. Bentuk universitas yang unik baik sebagai lembaga publik maupun entitas bisnis memiliki potensi risiko, di antaranya peningkatan kompleksitas dan volume transaksi, perubahan hukum terkait universitas, ekspektasi masyarakat yang tinggi untuk menghasilkan lulusan yang siap kerja, dan pengelolaan lembaga pendidikan yang mengalami perubahan, yang pada awalnya berbasis trust mulai bergeser kepada pengelolaan lembaga yang profesional. Risiko-risiko tersebut 
pada ujungnya akan mempengaruhi perkembangan praktek audit internal di dalam universitas. Universitas harus bergerak menjadi organisasi yang lebih efektif, efisien, dan memenuhi ekspektasi stakeholders.

\section{Dampak Fungsi Audit Internal terhadap Stakeholders}

Membentuk suatu fungsi audit internal di dalam suatu organisasi membutuhkan keinginan yang kuat oleh pihak manajemen dalam suatu organisasi, baik organisasi privat yang bersifat profit oriented, maupun organisasi publik yang bersifat non profit oriented. Hal ini terkait erat dengan adanya kesadaran organisasi tersebut untuk membenahi diri, dan keinginan untuk terus berkembang. Setelah suatu fungsi audit internal dalam organisasi tersebut terbentuk, banyak hal yang harus dihadapi didalam membentuk suatu fungsi audit internal yang efektif. Ada enam tema penting yang telah diidentifikasi dan perlu diperhatikan dalam membangun audit internal yang efektif, yaitu: persepsi dan kepemilikan, organisasi dan kerangka kepemimpinan, perundang-undangan atau peraturan, profesionalisme yang meningkat, kerangka konseptual, dan sumberdaya (Gansberghe 2005). Selain itu hal penting lain terkait dengan efektivitas adalah hubungan capaian kinerja dengan tujuan-tujuan yang ditetapkan. Di dalam organisasi publik suatu program dapat dikatakan efektif apabila capaiannya (outcome) sesuai dengan tujuannya (Omar et al., 2007)(Omar et al. 2007). Dengan memperhatikan hal-hal tersebut, diharapkan akan dapat terbentuk suatu fungsi audit internal yang efektif dan mampu meningkatkan pelayanan organisasi pada stakeholder. Hal ini penting karena stakeholder merupakan pihak yang akan merasakan dampak (impact) dari suatu program di dalam organisasi.

Mardiasmo (2005) menggolongkan berbagai macam stakeholder yang dimiliki suatu organisasi publik. Salah satu stakeholder yang digolongkan ke dalam external stakenolders adalah masyarakat luas sebagai pengguna jasa publik. Dalam hal ini Universitas sebagai lembaga pendidikan dan lembaga publik juga terkait dengan stakeholder ini (masyarakat). Stakeholder suatu organisasi publik tidak hanya masyarakat yang sekarang ada, namun termasuk juga generasi mendatang, yang akan menikmati manfaat maupun kerugian atas apa yang organisasi publik saat ini lakukan. Masyarakat baik secara langsung maupun tidak langsung akan merasakan manfaat apabila suatu fungsi audit internal dilakukan dengan efektif. Selain itu penelitian Montondon dan Fischer (1999) menyatakan bahwa stakeholder yang dimiliki oleh suatu universitas swasta (private university) adalah donor atau lembaga donor yang memberikan bantuan baik finansial maupun non finansial, para pembayar biaya pendidikan yang disediakan oleh universitas, mahasiswa, dan karyawankaryawan yang potensial. Efektivitas kinerja harus dibangun dan terus menerus ditingkatkan dengan memperhatikan kepentingan para stakeholders tersebut. Dari beberapa hal yang diungkapkan di atas dapat dipahami bahwa suatu fungsi audit internal dan kebutuhan akan pengingkatan efektivitasnya di dalam universitas dipengaruhi oleh kebutuhan stakeholders universitas. 


\section{Faktor-faktor yang Mempengaruhi Fungsi Audit Internal di Lembaga Publik}

Di dalam membangun suatu fungsi audit internal yang baik, perlu diperhatikan faktor-faktor yang dapat mempengaruhi fungsi audit internal tersebut. Penelitian yang dilakukan oleh Ahmad et al., (2009) di Malaysia, menunjukkan bahwa terdapat beberapa faktor utama yang dapat mempengaruhi aktivitas fungsi audit internal pada lembaga publik. Faktor-faktor tersebut yaitu:

Tabel 1

Faktor Kinerja Divisi Audit Internal

\begin{tabular}{ll}
\hline No. & \multicolumn{1}{c}{ Faktor-faktor } \\
\hline 1. & Audit staff (jumlah staff audit) \\
2. & Full support / commitment from top management (ada tidaknya dukungan dari manajemen \\
3. & Cooperation from auditee (kerjasama dari auditee) \\
4. & Training (pelatihan yang diikuti oleh auditor) \\
5. & Independence (independensi dari auditor) \\
6. & Competency / knowledge on auditing techniques (kompetensi / pengetahuan staff auditor pada \\
7. & Action on audit findings and recommendations by auditee / management (tindakan yang \\
8. & Experience of the staff in the IAF (pengalaman staff dalam fungsi audit internal) \\
9. & The Change of Head of Internal Auditors' Position (perubahan posisi kepala para internal \\
10. & Perception from auditee (persepsi dari auditee) \\
11. & Resources (sumber daya) \\
\hline Ahmad et al., (2009)
\end{tabular}

11. Resources (sumber daya)

etal., (2009)

\section{METODA PENELITIAN}

Penelitian ini merupakan sebuah penelitian kualitatif yang bermaksud untuk memahami fenomena tentang apa yang dialami oleh subjek penelitian, misalnya perilaku, persepsi, motivasi, tindakan, dan lain-lain, secara holistik, dan dengan cara deskripsi dalam bentuk kata-kata dan bahasa, pada suatu konteks khusus yang alamiah dan dengan memanfaatkan berbagai metode alamiah. Penelitian ini dilakukan dengan pendekatan kualitatif fenomenologi. Penelitian ini memfokuskan pada fenomena yang muncul di dalam Divisi Audit Internal Universitas X dan mendalaminya secara keseluruhan. Model penelitian yang dilakukan berupa penelitian single chase berupa studi pada Universitas X. Dari 11 faktor yang diungkapkan pada penelitian terdahulu (Ahmad et al., 2009) dilihat kondisinya pada fungsi internal audit Universitas X.

Data penelitian ini berkaitan dengan aktivitas fungsi internal audit yang dilakukan di Universitas X. Pengumpulan data primer dilakukan melalui wawancara. Data tersebut diperoleh dari berbagai pihak terkait, yaitu Pimpinan Universitas, Bendahara Pengurus Yayasan Universitas, Auditor Internal, mantan Auditor Internal, Anggota Komite Audit / mantan Anggota Komite Audit.

Peneliti juga menggunakan data sekunder yang diperoleh melalui studi dokumen terkait penerapan fungsi audit internal di Universitas X. Dokumen tersebut 
berupa SK Rektor, SK Yayasan, draft Piagam Audit Internal, dan draft Buku Manual Audit. Selanjutnya analisis dilakukan dengan cara mencatat maupun merekam hasil wawancara, melihat dan menganalisis bagaimana dampak kondisi faktor-faktor yang diungkapkan oleh Ahmad et al. (2009) maupun faktor-faktor di luar itu pada aktivitas fungsi audit internal pada Universitas X.

\section{ANALISIS DAN PEMBAHASAN}

\section{Divisi Audit Internal Universitas X}

Universitas $\mathrm{X}$ adalah sebuah universitas yang sudah berdiri lebih dari 50 tahun, dimana saat ini memiliki 13 Fakultas dan 69 Jurusan. Divisi Audit Internal Universitas $\mathrm{X}$ adalah sebuah divisi yang melakukan proses Audit Internal di dalam lembaga ini. Divisi ini berdiri sejak Juni 2007 dengan disahkannya pendirian divisi Audit Internal. Pada awalnya divisi ini direncanakan untuk berdiri di bawah Yayasan, dan bertugas melakukan audit internal terhadap Universitas X (beserta unitunit di bawahnya). Namun dalam perjalanannya akhirnya unit ini berada di bawah Rektor karena pada saat itu beberapa unit di bawah Universitas X masih membutuhkan bantuan di dalam hal pertanggungjawaban laporan keuangan. Untuk mengisi kebutuhan akan staf divisi ini, dilakukan proses rekrutmen terhadap staf yang nantinya akan menjadi auditor internal. Rekrutmen ini dilakukan oleh Para Anggota Komite Audit, yang pada awalnya merupakan anggota dari Gusgas Pembentukan Komite Audit dan Divisi Audit Internal (diangkat berdasarkan SK Rektor). Dari rekrutmen tersebut didapat 2 orang terbaik dari para pelamar. Satu orang diangkat menjadi Manajer Divisi Audit Internal dan 1 orang diangkat sebagai staff Divisi Auditor Internal. Dengan direkrutnya 2 staff tersebut serta pengajuan kontrak dari pimpinan universitas kepada Pengurus Yayasan, maka Divisi Auditor Internal Universitas $\mathrm{X}$ sudah resmi berdiri.

\section{Praktik Fungsi Audit Internal Universitas X}

Kegiatan audit internal yang dilakukan di Universitas $\mathrm{X}$ dapat dikatakan masih belum berjalan dengan baik semenjak didirikannya divisi internal audit di Universitas X pada 2007. Selama 6 tahun perjalanan proses audit internal di Universitas $\mathrm{X}$, ada beberapa hal yang menjadi indikasi hal tersebut serta menjadi perhatian peneliti pada praktik fungsi audit internal.

Pertama, pimpinan universitas belum menandatangani atau mengesahkan draf audit charter yang sudah disusun oleh Komite Audit Universitas X. Dengan demikian, kewenangan yang dimiliki oleh divisi Audit Internal di Universitas X belum jelas. Hal ini juga sebenarnya sedikit banyak menunjukkan sejauh mana dukungan dari pimpinan pada fungsi audit internal.

Kedua, selain belum disahkannya audit charter, buku manual audit yang telah disusun oleh staff audit internal pun belum dapat digunakan, karena belum 
mendapat pengesahan dari pihak pimpinan universitas. Hal ini membuat tidak adanya standar kinerja yang jelas, yang seharusnya dimiliki oleh suatu fungsi internal audit.

Ketiga, di dalam melakukan tugas pengawasan, fungsi audit internal Universitas $\mathrm{X}$ tidak membuat perencanaan kinerja seperti yang disyaratkan oleh Standar Nomor 2010 SPAI (YPIA, 2004), bahwa penanggungjawab fungsi audit internal harus menyusun perencanaan yang berbasis risiko untuk menetapkan prioritas kegiatan audit internal, konsisten dengan tujuan organisasi. Tidak adanya perencanaan dapat menyebabkan tidak efektifnya fungsi audit internal Universitas X.

Keempat, tidak adanya (tidak diperpanjangnya SK) Komite Audit di Universitas X. Menurut Sterck dan Bouckaert (2006) tidak adanya Komite Audit akan menyebabkan kinerja staff suatu fungsi audit internal menjadi tidak efektif. Saat dibentuk direncanakan staff audit internal ini adalah kepanjangan tangan dari Komite Audit dan roadmap kinerja fungsi audit internal akan ditentukan oleh Komite Audit.

Kelima, tugas yang dilakukan oleh staff audit internal Universitas X lebih berfokus kepada fungsi consulting, sedangkan fungsi pengawasan yang berujung pada pemberian assurance masih kurang. Fungsi dan tugas sebagai consulting agent ini berlangsung sampai saat ini. Selain itu, fungsi Divisi Audit Internal juga memiliki tugas sebagai pemeriksa di dalam kasus-kasus khusus. Apabila ditemukan adanya ketidakcocokan data (baik keuangan, maupun administratif) antara Universitas $\mathrm{X}$ dengan unit, staff Audit Internal akan diturunkan untuk mengatasi permasalahan yang muncul. Dari hal ini terlihat bahwa fungsi audit internal Universitas X berperan sebagai konsultan dan penolong apabila ada permasalahan yang timbul. Keenam, belum adanya ada koordinasi dan komunikasi antara Pengawas pada Yayasan yang merupakan salah satu organ sebagai Dewan Pengawas Organisasi dan bertugas mengawasi unit di bawah Yayasan (termasuk Universitas X) dengan Divisi Audit Internal.

\section{Faktor-faktor yang Mempengaruhi Aktivitas Divisi Audit Internal}

\section{Audit Staff (Jumlah Staff Audit Internal)}

Pada awal mula berdiri staf Divisi Audit Internal Universitas X berjumlah 2 orang yang terdiri dari seorang Manajer dan seorang staff auditor. Dua staf ini didapatkan pada saat open recruitment staff Divisi Audit Internal Universitas X pada 2007. Seperti diungkapkan oleh mantan Anggota Komite Audit (KA) Universitas X, direncanakan kedua staf ini yang akan menjadi perpanjangan tangan dari KA untuk melakukan fungsi pengawasan pada Universitas X. Dari para calon yang melamar menjadi staf didapatkan 2 orang terbaik (1 Manajer Divisi Audit Internal dan 1 Anggota Divisi Audit Internal). Setelah dibentuk, dalam perjalanannya Manajer Divisi Audit Internal dipindahtugaskan ke Bagian Akuntansi dan Keuangan (BAK) Universitas $X$ dan menjabat sebagai Manajer pada BAK. Sampai penelitian ini dilakukan, beliau masih menjabat sebagai Manajer BAK. 
Dari hasil wawancara yang dilakukan, didapat pemahaman mengenai faktor jumlah staff audit yang dapat mempengaruhi aktivitas fungsi audit internal. Dilihat dari sudut pandang manajemen puncak (pimpinan Universitas X), jumlah staf audit internal yang dimiliki oleh Universitas X dinilai sudah cukup, baik dari segi kuantitas maupun kualitas di dalam melakukan tugasnya (berjumlah 1 orang). Hal ini sesuai dengan yang dinyatakan oleh salah seorang pimpinan universitas,

"Pengurus merasa sudah cukup dengan Auditor 1, Auditor 2 sementara diminta untuk menangani Keuangan, staff audit internal yang ada saat ini sudah mumpuni di dalam melakukan tugasnya."

Seperti yang diungkapkan sebelumnya, Divisi Audit Internal Universitas X pada awal pembentukannya lebih banyak beroperasi sebagai consulting agent pada unit-unit di bawah Universitas $\mathrm{X}$, yang memiliki tugas membantu di dalam penyusunan laporan keuangan dan laporan pertanggungjawaban dari unit kepada Universitas X. Hal ini terlihat dari pernyataan salah seorang pimpinan universitas,

"Staff pada unit kadang tidak mumpuni di dalam menyusun laporan keuangan sehingga dibantu oleh Auditor Internal, membantu di dalam pemecahan masalah."

Selain itu divisi audit internal Universitas X juga memiliki tugas pengawasan. Hal ini dilakukan dengan melakukan pemeriksaan investigatif, baik dilakukan sendiri maupun dilakukan di dalam bentuk Satgas (berupa tim gabungan Staff Divisi Audit Internal dengan staff BAK). Dari interpretasi hasil wawancara yang dilakukan oleh peneliti, peneliti memperoleh pemahaman bahwa di dalam melakukan tugasnya sebagai consulting agent dan pemeriksa apabila terjadi kasus-kasus khusus tadi, pimpinan Universitas $\mathrm{X}$ memandang bahwa sudah cukup apabila dikerjakan oleh jumlah Auditor Internal yang dimiliki saat ini (termasuk dengan pembentukan satgas pada kasus-kasus tertentu yang skalanya besar).

Dari sudut pandang auditor internal dan mantan auditor internal, jumlah staff Divisi AI Universitas X (2 orang) sementara cukup dalam melakukan fungsi monitoring dan consulting terhadap Universitas $\mathrm{X}$ dan semua unit di bawahnya. Hal ini sesuai dengan yang diungkapkan oleh salah seorang mantan auditor internal,

"Untuk jumlah dua orang sebenarnya cukup kalau operasional juga sudah siap, laporan siap, tinggal (me)ngaudit."

Kendala yang dihadapi oleh divisi ini ditambah dengan adanya ketidakjelasan kewenangan dan prosedur operasional yang dimiliki. Dari hasil wawancara terungkap bahwa sebenarnya hal inilah yang menyebabkan seakan-akan jumlah dari staff sangat kurang, bahkan sampai dibentuk satgas untuk melakukan pemeriksaan pada kasus khusus. Hal ini sesuai dengan yang diungkapkan oleh salah seorang mantan auditor internal,

"Sampai sekarang saja dari audit charter dan manual book belum disahkan, padahal sudah saya buat semua tinggal di-acc." 
Di dalam pengalamannya bekerja pada fungsi audit internal, salah seorang narasumber mengungkapkan bahwa apabila perencanaan, prosedur, kewenangan, dan posisi internal auditor jelas, maka jumlah auditor internal Universitas X sudah cukup untuk melakukan pengawasan terhadap Universitas X.

Dari hasil wawancara dengan Bendahara Yayasan terungkap bahwa menurut pendapatnya jumlah auditor internal yang dimiliki oleh Universitas X saat ini masih kurang. Menurut pengalamannya jumlah auditor internal atau staff Sistem Pengendalian Internal sebesar Universitas $X$ tidak hanya dua orang. Ia mengungkapkan,

"Untuk staff SPI untuk mengawasi unit-unit di bawah Yayasan termasuk Universitas

$\mathrm{X}$, menurut pengalaman saya di Bank A, seharusnya staff SPI sebanyak 5-10 orang."

\section{Full Support / Comitment from Top Management}

Dukungan dari manajemen puncak untuk keberlangsungan suatu fungsi audit internal sangat penting karena akan berdampak pada peran apa yang dimiliki oleh suatu fungsi audit internal dalam suatu organisasi. Bahkan dukungan penuh dari manajemen dapat menutup kekurangan dan celah yang ditimbulkan dari kurangnya personel auditor internal (Ahmad et al., 2009). Selain itu pada penelitian Putra et al. (2016) menunjukkan bahwa gaya kepemimpinan yang diterapkan oleh manajemen puncak akan mempengaruhi secara signifikan kinerja auditor internal.

Dari hasil wawancara terungkap bahwa dukungan dari pimpinan universitas terlihat dari beberapa hal. Pertama, dukungan dalam bentuk akses yang diberikan terhadap fungsi internal audit. Dalam melakukan pemeriksaan terkait dengan adanya dugaan fraud dan error yang berkaitan dengan kelalaian keuangan dan administratif. Hal ini sesuai dengan yang diungkapkan oleh salah seorang pimpinan universitas,

"Kita mendukung penuh staff audit internal, kita berikan akses penuh karena internal auditor sangat penting untuk membantu menyelesaikan masalah."

Auditor internal maupun satgas dilengkapi surat tugas yang akan memudahkan proses pemeriksaan, dan memudahkan memperoleh informasi yang dibutuhkan untuk membuat kesimpulan. Hal ini dapat terjadi karena pimpinan universitas memandang bahwa fungsi audit internal merupakan suatu fungsi yang memiliki posisi strategis di dalam menemukan dan mencegah kesalahan terjadi pada unit-unit. Seperti yang diungkapkan salah seorang pimpinan universitas,

"kita berusaha mencegah kesalahan yang terjadi pada unit-unit, jadi Auditor Internal yang (mem)bantu."

Kedua, dukungan bantuan personel pada saat melakukan pemeriksaan investigatif dalam bentuk pendirian satgas khusus. Dalam menghadapi kasus-kasus tertentu yang bersifat besar (dalam kaitannya dengan jumlah anggaran / dana yang terlibat di dalamnya dan juga dampak yang ditimbulkan dari suatu kejadian), pimpinan membentuk satgas. Dimana satgas ini bertugas untuk mengumpulkan 
informasi, mendapatkan temuan, dan memberi rekomendasi terkait dengan kasus tersebut.

Namun di sisi yang lain, selain bentuk dukungan, terlihat juga bahwa ada beberapa hal yang dapat menghambat aktivitas fungsi audit internal Universitas X, yang bersumber dari pimpinan. Pertama, audit charter dan manual book yang belum disahkan oleh pimpinan Universitas X. Belum disahkannya audit charter sangat menghambat kinerja fungsi audit internal, karena di dalamnya memuat tujuan, kewenangan, dan tanggungjawab fungsi audit internal, sesuai yang disyaratkan pada Standar nomor 1000, SPAI (YPIA, 2004). Dengan belum disahkannya audit charter, tidak ada batasan yang jelas mengenai tujuan, kewenangan, dan tanggungjawab fungsi audit internal. Kedua, tidak adanya sumber daya finansial yang disediakan oleh pimpinan terkait dengan aktivitas pengawasan (selain gaji staff audit internal). Hal ini menunjukkan bahwa dari sudut pandang finansial tidak terlihat dukungan penuh dari pimpinan universitas (top management). Ketiga, dari hasil wawancara terungkap bahwa dari segi aturan, untuk divisi audit internal sebenarnya sudah disiapkan, namun dari segi pelaksanaan masih belum berjalan dengan baik. Menurutnya hal ini kemungkinan diakibatkan oleh Pimpinan Yayasan dan Pimpinan Universitas $\mathrm{X}$ yang tidak memiliki latar belakang ekonomi sehingga para pimpinan tersebut tidak menganggap sistem pengendalian internal adalah sesuatu yang penting. Hal itu sesuai dengan yang diungkapkan oleh bendahara yayasan,

“...keterbatasan pemimpin pasti ada, semisal pemimpin ada yang memeriksa nota dan lain-lain, tapi kalau tidak memiliki background ekonomi apa ya tahu?”

"Pengurus sudah memandang penting SPI tapi organ yang lain kok sepertinya belum" (catatan: Organ Pembina Yayasan beranggotakan perwakilan gereja-gereja)

\section{Cooperation from Auditee}

Kerjasama dari auditee sangat berpengaruh pada proses audit internal di dalam suatu organisasi. Hal ini disebabkan kurangnya kerjasama dari auditee akan menghalangi usaha untuk mencapai kerja audit internal yang efektif. Hal tersebut muncul karena akses yang dimiliki oleh auditor internal, baik terhadap aktivitas operasi, catatan, dan properti akan sangat terbatas (Ahmad et al., 2009). Pada awal pembentukan divisi audit internal Universitas $\mathrm{X}$, di dalam melakukan prosedur pemeriksaan investigatif, auditor mendapat banyak penolakan dan resistensi yang kuat dari auditee. Dari hasil wawancara terungkap bahwa hal ini terjadi akibat saat pembentukan, divisi ini seakan akan mengubah operasional unit yang selama bertahun-tahun sudah berjalan. Selain itu terungkap pula dari hasil wawancara, ada sebagian auditee yang memiliki pemikiran bahwa divisi audit internal seakan dibuat hanya untuk mencari-cari kesalahan auditee. Hal ini sesuai dengan yang diungkapkan mantan Manajer Divisi Audit Internal,

"di awal unit merasa hanya ditunjukkan ini kesalahanmu, kadang unit mikir kalau audit cuma bisa omong thok, ya sudah akhirnya kita bantu bikin laporan keuangan." 
Pada pemeriksaan-pemeriksaan awal, auditor menggunakan surat tugas sebagai dasar melakukan pengumpulan informasi dan pemeriksaan, sehingga mau tidak mau auditee akan memberikan akses yang penuh pada auditor internal. Namun disebabkan oleh faktor "kebiasaan", dan sama-sama bekerja dalam satu organisasi, terbentuk budaya kerja "kekeluargaan" antara auditee dan auditor internal. Hal ini sesuai dengan yang diungkapkan oleh Anggota Divisi Audit Internal,

"waktu mengaudit unit dibaik-baiki, sampe pernah kita tawari untuk menagihkan uang yang macet."

Selanjutnya di dalam pemeriksaan-pemeriksaan berikutnya pada unit yang terdapat permasalahan atau kasus khusus, auditor menggunakan pendekatan kekeluargaan. Dari sisi lain, auditee juga merasa tidak terjadi ketegangan lagi sewaktu menjalani proses audit dan pemeriksaan investigatif, kecuali untuk beberapa person yang melakukan pelanggaran.

Dari hasil wawancara terlihat bahwa pada awal dibentuknya divisi internal, terdapat penolakan yang kuat dari auditee untuk menerima proses audit dan pemeriksaan dari divisi audit internal. Namun pada selanjutnya pada waktu-waktu setelah itu, kerjasama "kekeluargaan" yang terbentuk antara auditor internal dengan auditee, ditambah dengan SK Rektor menyebabkan proses audit dan pemeriksaan investigatif berjalan dengan lancar.

\section{Training}

Training atau pelatihan personel adalah salah satu cara meningkatkan kemampuan dan kompetensi staff. Ahmad et al. (2009) menemukan bahwa pelatihan yang kurang, menyebabkan efektivitas dari fungsi audit internal dalam organisasi publik. Selain itu Sterck dan Bouckaert (2006) menungkapkan bahwa salah satu syarat agar divisi audit internal memiliki kinerja yang efektif adalah adanya strategi untuk pengembangan kompetensi staf fungsi audit internal. Dari hasil wawancara yang dilakukan terhadap beberapa narasumber terungkap beberapa hal mengenai pelatihan staff audit internal di Universitas X. Pertama, pada saat pembentukan awal, sudah pernah direncanakan pelatihan yang berkaitan dengan kompetensi staff divisi audit internal, namun belum pernah terealisasi. Hal ini sesuai dengan yang diungkapkan oleh salah seorang auditor internal,

"Rencana (pelatihan) ada, tapi itu hanya sebatas wacana". "(Pelatihan) itu direncanakan sebelum kita (auditor internal) masuk."

Kedua, pihak pimpinan universitas merasa bahwa kemampuan staff yang ada saat ini sudah mumpuni di dalam melakukan tugas dimilikinya (melakukan consulting service kepada unit-unit di bawah Universitas $\mathrm{X}$ dan melakukan peran pemeriksa investigatif pada kasus-kasus khusus), yang diperbaiki justru dari sisi unit agar dapat membuat laporan dengan baik. Hal ini sesuai dengan yang diungkapkan oleh salah seorang pimpinan universitas, 
"pelatihan staff audit internal tidak ada karena sudah mumpuni. Pelatihan yang ada untuk unit."

Dua hal yang didapat dari praktik audit internal di Universitas $X$ menunjukkan selama 6 tahun dari pendiriannya tidak ada Pengembangan Profesional yang Berkelanjutan (PPL) seperti yang disyaratkan oleh Standar nomor 1230 SPAI (YPIA, 2004), yang merupakan inisiatif pihak yang pimpinan/yang bertanggungjawab terhadap fungsi audit internal Universitas X. Namun di sisi lain, salah seorang staf audit internal memiliki inisiatif untuk meningkatkan kompetensinya dengan mengambil pendidikan Magister (S2) Akuntansi, dengan penjurusan auditing.

Belum direncanakannya pengembangan ke depan untuk kompetensi staff tentu saja merupakan kelemahan di dalam divisi audit internal Universitas X. Hal ini terjadi karena kemungkinan pimpinan merasa staf yang dimiliki oleh divisi audit internal sudah kompeten di dalam melakukan tugasnya. Hal yang mesti diantisipasi oleh manajemen adalah apabila terjadi peningkatan kompleksitas transaksi dan sistem (Akmal 2009). Dengan adanya hal tersebut tentu saja juga harus ada peningkatan kompetensi staff audit internal untuk dapat memberikan tingkat assurance yang memadai. Dalam hal ini pelatihan sangat diperlukan dalam upaya peningkatan tersebut.

\section{Independence}

Indikator independensi dapat dilihat dari posisi fungsi auditor internal di dalam suatu organisasi. Posisi fungsi audit internal di Universitas X berada di bawah Rektor. Meskipun demikian, dalam operasionalnya sehari-hari staf audit internal akan melapor kepada Pembantu Rektor II (PR). Setelah itu PR yang akan melaporkan laporan rutin atau hasil temuan pemeriksaan investigatif kepada Rektor. Yang menjadi perhatian pada faktor independensi ini adalah posisi Divisi Audit Internal Universitas $X$ yang berada di bawah Rektor menyebabkan, divisi ini tidak akan bisa independen apabila melakukan pemeriksaan terhadap pimpinan.

Dari hasil wawancara yang dilakukan, terlihat bahwa posisi auditor internal yang berada di bawah Rektor, dan memberikan pertanggungjawaban kepada Rektor melalui PR II dirasa kurang independen karena belum disahkannya internal audit charter dan manual book. Hal ini sesuai dengan yang diungkapkan salah seorang mantan anggota komite audit,

"Auditor harusnya independen, meskipun di bawah Rektor tapi seharusnya ada pengesahan internal audit charter dan manual book."

Pada praktiknya di Universitas $\mathrm{X}$ Rektorat memperoleh pengesahan penggunaan anggaran dari Yayasan. Penggunaan anggaran tersebut diharapkan efektif dan efisien. Auditor Internal juga seharusnya melakukan audit terhadap Rektorat untuk melihat efektivitas dan efisiensi, namun posisi divisi audit internal 
tersebut kurang memungkinkan untuk dapat memberikan hasil audit yang independen.

Dari hasil wawancara didapatkan pula informasi bahwa sebenarnya Divisi Audit Internal Universitas X diharapkan sebenarnya untuk berada dibawah Pengawas Yayasan dan dapat melakukan pengawasan yang penuh dan independen terhadap Pengurus Yayasan dan unit-unit di bawahnya. Hal ini sesuai yang diungkapkan oleh bendahara yayasan,

\begin{abstract}
“...sebenarnya harusnya SPI berada di bawah (Organ) Pengawas (Yayasan) dan menjadi kepanjangan tangan Pengawas untuk mengawasi Pengurus dan unit-unit. Seperti di perbankan harusnya berada di bawah Dewan Komisaris sehingga dapat mengawasi direksi dengan full."
\end{abstract}

\title{
Competency / Knowledge on Auditing Techniques
}

Tiga keahlian utama auditor internal yang dibutuhkan oleh perusahaan pada saat ini berfokus pada kemampuan analisis, kemampuan komunikasi, dan kemampuan akuntansi (Roth dan Soileau 2016), dimana hal ini cukup mengejutkan bahwa kemampuan akuntansi masuk di dalam tiga besar kemampuan yang dibutuhkan oleh perusahaan. Dua staf internal audit yang direkrut oleh fungsi audit internal Universitas X, keduanya merupakan lulusan S1 Akuntansi yang di dalamnya sudah memuat materi dan teknik-teknik pengauditan. Dilihat dari latar belakang pendidikan, kedua auditor internal sudah mendapatkan materi bagaimana teknis melakukan prosedur audit. Selanjutnya staf Auditor Internal dengan inisiatif sendiri mengambil program pendidikan Magister Akuntansi dengan penjurusan ke bidang auditing. Sedangkan Manajer Audit Internal mengambil program pendidikan Magister Manajemen. Dari sisi pengalaman kerja, Manajer Audit Internal pernah bekerja pada kantor akuntan publik (KAP) dan melakukan audit pada beberapa klien. Dari beberapa hal tersebut, dapa dipahami bahwa kedua staff audit internal telah memiliki kompetensi yang memadai terkait dengan prosedur audit dan teknik-teknik audit. Hal ini sesuai dengan yang diungkapkan oleh salah seorang mantan auditor internal,

"Kalau secara teori saya gak (h)apal teknik, tapi kalau disuruh melakukan audit saya bias."

\section{Action on Audit Findings and Recommendations by Auditee / Management}

Dalam melakukan pemeriksaan investigatif pada praktik di Universitas $X$, auditor internal membuat suatu dokumen yang berisi laporan terkait dengan temuan dari kasus-kasus tertentu yang muncul. Laporan tersebut diberikan kepada PR yang kemudian mengajukan kepada Rektor dan dibahas bersama-sama pada Rapat Pimpinan. Dari hasil wawancara, setiap ada laporan baik hasil temuan yang formal, maupun laporan lisan yang kurang formal, akan selalu ditindaklanjuti oleh pimpinan. Tindaklanjut yang dilakukan oleh pimpinan dapat diputuskan sendiri oleh PR apabila tidak merupakan hal yang material, namun untuk hal yang bersifat masif / material 
akan diajukan kepada rapat pimpinan universitas. Hal ini sesuai yang diungkapkan oleh salah seorang pimpinan universitas,

"Setiap laporan yang disampaikan staff audit internal selalu ditindaklanjuti, untuk upaya menyelesaikan masalah". "Auditor internal melapor berkala, fleksible, kalau ada yang urgent harus dirapatkan."

Dari hasil wawancara terungkap bahwa setiap temuan maupun laporan yang diberikan oleh staff audit internal akan selalu ditindaklanjuti oleh pimpinan. Untuk tindak lanjut yang dilakukan oleh auditee tergantung dari keputusan yang diambil oleh pimpinan kepada auditee. Hal ini disebabkan oleh posisi auditee yang merupakan unit-unit yang berada di bawah Universitas X.

\section{Experience of the staff in the Internal Audit Function}

Menurut Wandita et al. (2014) pengalaman menjadi satu indikator yang mendukung kualitas hasil kerja seorang auditor internal. Dapat dipahami bahwa semakin banyak pengalaman kerja, maka semakin baik kualitas hasil pemeriksaan yang dilakukannya. Pengalaman kerja juga sangat mempengaruhi keputusan yang akan diambil, semakin lama seorang auditor menekuni profesinya maka akan semakin tepat dalam mendeteksi adanya sebuah kesalahan.

Kedua staff yang direkrut pada saat open recruitment adalah para calon yang terbaik yang mendaftar untuk menjadi staf Divisi Audit Internal Universitas X. Dari hasil wawancara dan data yang diterima oleh peneliti menunjukkan bahwa dari dua staff divisi audit internal tersebut, hanya Manajer Divisi Audit Internal yang telah berpengalaman pada bidang Audit Internal. Sebelum menjadi Manajer Divisi Audit Internal Universitas X, beliau bekerja pada sebuah KAP, serta menjadi Manajer Departemen Audit Internal pada sebuah perusahaan yang bergerak di bidang otomotif. Sedangkan Anggota Tim Audit Internal sebelum menjadi staf Divisi Audit Internal Universitas $X$, bekerja pada sebuah perusahaan kontainer sebagai staff keuangan dan operasional. Setelah Manajer Divisi Audit Internal dipindahtugaskan menjadi Manajer BAK, kemungkinan terjadi beberapa permasalahan. Pertama, jumlah anggota divisi audit internal yang sangat minim dapat menyebabkan kinerjanya tidak efektif. Kedua, Manajer Divisi Audit Internal adalah satu-satunya staff divisi audit internal yang memiliki banyak pengalaman di dalam bidang audit internal, sehingga dipindahtugaskannya beliau dapat mengganggu kinerja divisi audit internal.

\section{The Change of Head of Internal Auditors' Position}

Posisi dari Manajer Divisi Audit Internal di Universitas X tidak pernah berubah dari posisi awalnya. Pada pembentukan awal posisi divisi ini direncanakan akan berada di bawah Yayasan, sehingga memiliki posisi yang strategis untuk dapat melakukan pemeriksaan dan pengawasan terhadap seluruh unit yang berada di bawah Yayasan. Namun pada saat itu memandang sudah adanya Dewan Pengawas pada Yayasan, dan mempertimbangkan bahwa Universitas $\mathrm{X}$ adalah unit terbesar pada 
Yayasan, maka internal auditor ditempatkan di bawah Rektor terlebih dahulu. Selanjutnya direncanakan apabila fungsi ini sudah settle maka akan dibawa kepada aras Yayasan. Hingga saat ini posisi divisi audit internal belum pernah mengalami perubahan. Namun sebaliknya, melihat pada posisi kepala audit internal (manajer) pada divisi audit internal Universitas X pernah berubah. Hal ini terjadi pada saat Manajer Divisi Audit Internal dipindahtugaskan menempati posisi Manajer BAK. Hal ini kemungkinan dapat mempengaruhi kinerja divisi audit internal Universitas X, karena beliau adalah orang yang paling berpengalaman di dalam fungsi audit internal.

\section{Perception from Auditee}

Persepsi dari auditee, akan sangat berhubungan dengan kerjasama dari auditee. Persepsi yang positif akan mengarah kepada kepuasan terhadap kinerja auditor (Tanuwidjaja \& Wibisono 2015). Pada saat dibentuk divisi audit internal dan auditor mulai melakukan pemeriksaan, terdapat penolakan dan resistensi yang dilakukan oleh auditee. Hal ini sesuai dengan yang diungkapkan oleh salah seorang mantan anggota komite audit,

"pada awal dibentuk memang ada resistensi yang kuat dari unit terhadap divisi audit internal."

Bahkan dari hasil wawancara terungkap beberapa auditee beranggapan bahwa auditor internal direkrut hanya untuk mencari-cari kesalahan, dan sebenarnya tidak dapat mengerjakan laporan yang harus dibuat oleh auditee. Namun setelah berjalannya waktu penolakan tersebut mulai berkurang.

Persepsi dari auditee mulai berubah disebabkan, setelah berjalan beberapa saat tugas auditor internal diperluas menjadi tugas consulting, yang akan membantu auditee di dalam membuat laporan. Selain itu auditee mau tidak mau dipaksa untuk bekerjasama dengan auditor, baik memberikan keterangan maupun memberikan akses terhadap catatan dan dokumen kepada auditor karena di setiap penugasan auditor selalu memakai SK yang diterbitkan oleh pimpinan.

\section{Resources}

Tren saat ini sumber daya yang dibutuhkan oleh fungsi audit internal, pada perkembangan audit internal di Amerika, universitas mulai menambahkan anggaran untuk melakukan pengujian data secara analitis (Jackson 2014). Terdapat beberapa sumberdaya maupun fasilitas yang didapatkan oleh divisi audit internal Universitas $X$. Pertama, fasilitas berupa laptop kerja, yang digunakan untuk menyimpan data dan membuat laporan pemeriksaan investigatif. Kedua, ruang kerja yang digabung dengan ruang kerja BAK. Ketiga, insentif di dalam melakukan pemeriksaan pada kasus tertentu (di dalam bentuk satgas). Keempat, akses penuh terhadap informasi yang terkait dengan auditee pada pemeriksaan investigatif dan kegiatan consulting. Di lihat dari sudut pandang finansial, belum ada anggaran khusus yang digunakan untuk melakukan perencanaan pemeriksaan, dan tindakan pemeriksaan, kecuali gaji 
staff audit internal. Hal tersebut sesuai dengan yang diungkapkan oleh salah seorang auditor internal,

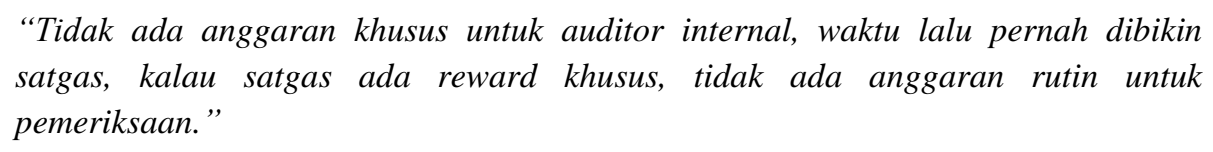

Hal ini disebabkan karena posisi staf divisi audit internal yang berada di bawah Rektor (sebagai staf Rektor) serta tidak ada pos anggaran khusus untuk divisi audit internal Universitas X. Anggaran yang terkait dengan divisi audit internal Universitas X berada pada pos anggaran Rektor. Beberapa hal yang terungkap tersebut kemungkinan akan menimbulkan beberapa implikasi. Pertama, tidak independennya divisi audit internal dengan pimpinan, apabila di masa datang akan melakukan audit terhadap pimpinan. Kedua, beberapa fasilitas yang diberikan kepada divisi audit internal kemungkinan mempengaruhi kinerja staf, sebagai contoh: apabila akan melakukan audit terhadap BAK.

\section{Rangkuman Kondisi Faktor-Faktor yang Mempengaruhi Aktivitas Fungsi Audit Internal di Universitas X}

Dari analisis yang telah dipaparkan di atas mengenai faktor-faktor yang mempengaruhi fungsi audit internal, disajikan ringkasan pengaruh dari faktor-faktor tersebut terhadap praktek audit internal di Universitas X (Tabel 2, lampiran).

Dari data pada Tabel 2 (lampiran) mengenai faktor yang mempengaruhi aktivitas fungsi audit internal menurut Ahmad et al. (2009), terlihat bagaimana kondisi faktorfaktor yang dapat mempengaruhi aktivitas fungsi audit internal baik mendukung atau tidak mendukung fungsi tersebut. Selain dari faktor-faktor tersebut, terdapat juga beberapa hal yang perlu mendapat perhatian mengenai praktek audit internal pada Universitas X secara keseluruhan, yaitu tidak adanya Komite Audit. Komite Audit inilah yang pada awal pembentukan divisi audit internal direncanakan akan memetakan apa yang akan dikerjakan oleh staf audit internal. Selanjutnya hal lain yang muncul pada praktik fungsi audit internal di Universitas $X$ adalah tidak adanya perencanaan mengenai program audit yang akan dilakukan oleh divisi audit internal. Hal tersebut kemungkinan terjadi akibat tidak adanya Komite Audit dan komunikasi yang ada antara Pimpinan Universitas, Komite Audit, dan Pengawas pada Yayasan tidak terintegrasi dengan baik untuk mengatur divisi audit internal.

\section{SIMPULAN, KETERBATASAN DAN SARAN}

\section{Kesimpulan}

Berdasarkan hasil penelitian, dapat ditarik kesimpulan bahwa kondisi untuk masing-masing faktor yang diduga mempengaruhi aktivitas divisi audit internal Universitas $\mathrm{X}$ berbeda-beda. Hal ini berdasarkan persepsi narasumber penelitian ini sebagai stakeholders fungsi audit internal Universitas X. Faktor-faktor tersebut 
secara langsung maupun tidak langsung telah mempengaruhi aktivitas divisi audit internal Universitas X. Dari beberapa faktor yang sudah diungkapkan, beberapa faktor yang ternyata mendukung aktivitas divisi audit internal di Universitas X adalah kerjasama dari auditee, kompetensi / pengetahuan staff dalam teknik-teknik audit, tindaklanjut dari temuan dan rekomendasi oleh auditee / manajemen, serta pengalaman dari staff pada fungsi audit internal. Sedangkan beberapa faktor yang tidak mendukung aktivitas divisi audit internal di Universitas $\mathrm{X}$ adalah jumlah staff audit internal, dukungan / komitmen dari manajemen puncak, pelatihan, independensi, perubahan posisi kepala auditor internal, persepsi dari auditee, serta sumberdaya. Selain faktor-faktor yang diungkapkan oleh Ahmad et al. (2009) tersebut, peneliti juga menemukan beberapa faktor yang kemungkinan juga mempengaruhi aktivitas dan praktek audit internal di Universitas X. Pertama, belum disahkannya audit charter dan manual book. Kedua, tidak adanya perencanaan untuk melakukan audit pada unit-unit. Ketiga, tidak adanya (tidak diperpanjangnya SK) Komite Audit. Keempat, divisi audit internal tidak pernah berkomunikasi dengan Pengawas Yayasan, selaku dewan pengawas organisasi.

Berdasarkan analisis faktor-faktor tersebut, dapat dipahami mengapa saat ini aktivitas atau praktek audit internal di Universitas $\mathrm{X}$ belum berlangsung sebagaimana mestinya (pengawasan dan consulting bagi manajemen). Akibat belum disahkannya audit charter dan manual book membuat fungsi audit internal Universitas $\mathrm{X}$ di dalam aktivitasnya mengalami kegagalan di dalam mempraktekkan fungsi audit internal yang efektif. Selama ini lebih banyak membantu membuatkan laporan keuangan unit dan menjadi pencari solusi untuk kasus-kasus tertentu. Belum terlihat bagaimana fungsi pengawasan yang seharusnya dimiliki oleh fungsi audit internal dalam suatu organisasi.

\section{Implikasi}

Hal-hal ini dapat mulai diimplementasikan agar aktivitas fungsi audit internal Universitas X dapat bekerja lebih efektif, beberapa di antaranya yaitu: Pertama, penetapan posisi yang strategis bagi divisi audit internal, yang dapat menunjang independensi dan dapat memperkuat fungsi pengawasan fungsi audit internal. Kedua, disahkannya audit charter dan manual book. Ketiga, kebijakan yang jelas dari pimpinan universitas mengenai tugas dan kewenangan Divisi Audit Internal. Keempat, dibuatnya rencana pelatihan bagi auditor internal dan ditingkatkannya jumlah pelatihan bagi unit. Kelima, posisi kepala auditor internal yang tidak dirubahrubah/rangkap jabatan dengan posisi lain dalam organisasi. Keenam, memberikan pengertian kepada seluruh anggota organisasi mengenai pentingnya pengawasan internal, terutama kepada auditee. Ketujuh, penanggungjawab organisasi mulai memikirkan perencanaan pemeriksaan secara berkala dan terstruktur, termasuk sumberdaya keuangan khusus khusus untuk aktivitas pengawasan. Kedelapan, pembentukan ulang Komite Audit Universitas X. Kesembilan, komunikasi antar stakeholders organisasi harus diperbaiki, agar terciptanya lingkungan pengawasan 
yang baik. Kesepuluh, peningkatan dan pembenahan governance yang perlu dilakukan dari Yayasan, dan manajemen tingkat atas hingga bawah.

\section{Keterbatasan dan Saran}

Penelitian ini dilakukan sebagian besar dengan mendasarkan pada hasil wawancara yang dilakukan pada beberapa key person sehingga kemungkinan tingkat subjektivitas yang disampaikan sangat tinggi. Selanjutnya model penelitian ini hanya mengacu pada sebelas faktor yang diungkapkan oleh (Ahmad et al., 2009) sehingga tidak bisa mengakomodasi faktor-faktor lainnya yang kemungkinan juga dapat mempengaruhi kinerja Divisi Audit Internal. Penelitian mendatang sebaiknya menggunakan teknik pengumpulan data yang lebih kaya untuk dapat meningkatkan tingkat objektivitas, serta dapat mempertimbangkan faktor-faktor lain yang digunakan sebagai kerangka penelitian untuk melihat pengaruhnya pada fungsi audit internal.

\section{DAFTAR PUSTAKA}

(YPIA), Yayasan Pendidikan Internal Audit. 2004. Standar profesi audit internal. Jakarta: Yayasan Pendidikan Internal Audit.

Akmal. 2009. Pemeriksaan manajemen internal audit. Edisi Kedu. Jakarta: PT Indeks.

Anderson, Urton. 2003. "Assurance and consulting services." In Research opportunities in internal auditing, Edisi 4, 97-129. Altamonte Springs: FL: Institute of Internal Auditors Research Foundation.

Cohen, Aaron, dan Gabriel Sayag. 2010. "The effectiveness of internal auditing: an empirical examination of its determinants in Israeli organisations." Australian Accounting Review 10 (54): 296-307. https://doi.org/10.1111/j.18352561.2010.00097.x.

Eckel, P. D., dan A. Kezar. 2006. The challenge facing academic decision making: responding to new priorities, following new pathways. Washington DC: ACE/Praeger Book Series.

Ferlie, Ewan, dan Edoardo Ongaro. 2015. Strategic management in public service organizations: concepts, schools and contemporary issues. New York, USA: Routledge.

Florea, Ramona Radu. 2013. "Internal audit and corporate governance." Economy Transdisciplinarity Cognition 16 (1): 79-83.

Gansberghe, C. N. Van. 2005. "Internal auditing in the public sector." The Internal Auditor (August), 2005.

Jackson, R. A. 2014. “The year ahead: 2015.” The Internal Auditor (December). 
Mahsun, Mohammad, dan Firma Sulistiyowati. 2007. Akuntansi sektor publik. Yogyakarta: BPFE-Yogyakarta.

Mardiasmo. 2005. Akuntansi sektor publik. Jakarta: Andi.

Moeller, Robert R. 2009. Brink's modern internal auditing: a common body of knowledge: seventh edition. John Wiley \& Sons, Inc. New Jersey, USA: John Wiley \& Sons, Inc. https://doi.org/10.1002/9781118371558.

Montondon, L. G., dan M. Fischer. 1999. "University audit departments in the united states." Financial Accountability \& Management 15 (1): 85-94.

nasibah Ahmad, Halimah, Radiah Othman, Rohana Othman, dan Kamaruzaman Jusoff. 2009. "The effectiveness of internal audit in Malaysian public sector." Journal of Modern Accounting and Auditing 5 (9): 53-62. https://doi.org/http://ssrn.com/abstract=2162236.

Omar, O., H. I. M. Sharofi, S. I. Syed-Soffian, H. S. Zabedah, H. R. Mohd-Shahrir, dan M. S. Md-Suhaimi. 2007. Public sector accounting in Malaysia. Kuala Lumpur, Malaysia: Thompson Learning.

Parker, Lee. 2011. "University corporatisation: driving redefinition." Critical $\begin{array}{lllll}\text { Perspectives on } & 22 & \text { (1): } & \text { 4ccounting }\end{array}$ https://doi.org/10.1016/j.cpa.2010.11.002.

Putra, I. N. W., E. Sujana, dan I. G. A. Purnamawati. 2016. "Pengaruh locus of control, gaya kepemimpinan, dan kompleksitas tugas terhadap kinerja auditor internal." Jurnal Ilmiah Mahasiswa Akuntansi 4 (1): 1-3.

Roth, James, dan Laura Soileau. 2016. "Internal audit fundamentals: the most basic skills remain largerly uncanghed." The Internal Auditor (February), 2016.

Sterck, M, dan G Bouckaert. 2006. "Iternational audit trends in the public sector." The Internal Auditor (April), 2006.

Tanuwidjaja, S, dan S. H. Wibisono. 2015. "Persepsi dan harapan auditee terhadap kualitas audit serta pengaruhnya terhadap kepuasan auditee." Jurnal Ilmu Manajemen dan Akuntansi 3 (2): 40-44.

Vijayakumar, A N, dan N. Nagaraja. 2012. "Internal control systems : effectiveness of internal audit in risk management at public sector enterprises." BVIMR Management Edge 5 (1): 1-8.

Wandita, N. L. P. T. A., G. A. Yuniarta, dan N. A. S. Darmawan. 2014. "Pengaruh pengetahuan, pengalaman kerja audit, dan akuntabilitas terhadap kualitas hasil kerja auditor internal." Jurnal Ilmiah Mahasiswa Akuntansi 2 (1): 1-3.

Willson, C, R. Negoi, dan A. S. Bhatnagar. 2010. "University risk anagement." The Internal Auditor (August), 2010. 


\section{LAMPIRAN}

Tabel 2

Ringkasan Pengaruh Faktor-faktor

\begin{tabular}{|c|c|c|}
\hline No. & Aspek / Faktor & Kondisi \\
\hline 1. & Audit Staff & $\begin{array}{l}\text { - Jumlah staff audit internal yang dimiliki oleh } \\
\text { Universitas X dipandang belum cukup oleh narasumber } \\
\text { untuk melakukan tugas pengawasan dan consulting } \\
\text { pada Universitas X dan seluruh unit di bawahnya. } \\
\text { - Untuk organisasi sebesar Universitas X dengan } \\
\text { kerumitan transaksi di dalamnya, Bendahara Yayasan } \\
\text { berpikir bahwa tidak cukup kalau hanya } 2 \text { orang (dengan } \\
1 \text { orang staff diangkat menjadi Manajer BAK) yang } \\
\text { memegang kunci pengawasan di Universitas X. }\end{array}$ \\
\hline 2. & $\begin{array}{l}\text { Full Support / Commitment from } \\
\text { top management }\end{array}$ & $\begin{array}{l}\text { - Belum disahkannya internal audit charter menyebabkan } \\
\text { auditor internal tidak independen, serta tidak jelasnya } \\
\text { batasan kewenangan dan tugas yang dikerjakan oleh } \\
\text { staff audit internal. } \\
\text { - Belum disahkannya manual book menyebabkan tidak } \\
\text { jelasnya tugas, dan prosedur yang harus dilakukan oleh } \\
\text { staff audit internal. } \\
\text { - Meskipun anggaran dasar sudah ada, namun pelaksanaan } \\
\text { Divisi Audit Internal belum berjalan dengan baik karena } \\
\text { SPI kemungkinan belum dianggap penting (terkait latar } \\
\text { belakang Pimpinan yang non ekonomi). }\end{array}$ \\
\hline 3. & Cooperation from auditee & $\begin{array}{l}\text { - Auditee mau tidak mau dipaksa bekerja sama dengan } \\
\text { auditor di dalam baik di dalam penugasan consulting } \\
\text { maupun pemeriksaan investigatif karena auditor maupun } \\
\text { satgas menggunakan surat tugas / surat keputusan Rektor } \\
\text { (SK). }\end{array}$ \\
\hline & & $\begin{array}{l}\text { - Program pelatihan yang direncanakan oleh Komite Audit, } \\
\text { tidak pernah terealisasi. }\end{array}$ \\
\hline 4. & Training & $\begin{array}{l}\text { - Tidak ada inisiatif dari top management untuk } \\
\text { mengadakan pelatihan kepada staff audit internal karena } \\
\text { menganggap staff audit internal sudah mumpuni di } \\
\text { dalam melakukan tugasnya. }\end{array}$ \\
\hline 5. & Independence & $\begin{array}{l}\text { - Posisi auditor internal yang berada di bawah Rektor } \\
\text { (sebagai staff Rektor) menyebabkan tidak independennya } \\
\text { auditor internal terhadap top management (Pimpinan } \\
\text { Universitas X). }\end{array}$ \\
\hline 6. & $\begin{array}{l}\text { Competency / knowledge on } \\
\text { auditing techniques }\end{array}$ & $\begin{array}{l}\text { - Staff audit internal yang dimiliki sudah memiliki latar } \\
\text { belakang pendidikan yang mendukung terkait dengan } \\
\text { pengetahuan mengenai teknik-teknik audit. } \\
\text { - Dalam melakukan pemeriksaan investigatif, staff audit } \\
\text { internal mempraktekkan prosedur audit sesuai dengan } \\
\text { pengalaman pekerjaan. }\end{array}$ \\
\hline 7. & $\begin{array}{l}\text { Action on audit findings and } \\
\text { recommendation by auditee / }\end{array}$ & $\begin{array}{l}\text { - Penyampaian laporan yang sangat mudah tanpa hambatan } \\
\text { birokrasi berarti. }\end{array}$ \\
\hline
\end{tabular}




\begin{tabular}{|c|c|c|}
\hline No. & Aspek / Faktor & Kondisi \\
\hline & management & $\begin{array}{l}\text { - Hasil temuan yang pasti ditindaklanjuti oleh pimpinan. } \\
\text { - Auditee pasti melaksanakan keputusan dari pimpinan } \\
\text { Universitas X, karena posisi auditee berada di bawah } \\
\text { Universitas X }\end{array}$ \\
\hline & Experience of the staff in the & $\begin{array}{l}\text { - Kedua staff audit yang memiliki latar belakang pekerjaan } \\
\text { di bidang akuntansi dan keuangan. }\end{array}$ \\
\hline 8. & internal audit function & $\begin{array}{l}\text { - Salah satu staff audit internal sangat berpengalaman di } \\
\text { dalam bidang khusus auditing dan audit internal. }\end{array}$ \\
\hline 9. & $\begin{array}{l}\text { The Change of Head of Internal } \\
\text { Auditors' position }\end{array}$ & $\begin{array}{l}\text { - Meskipun tidak pernah ada perubahan posisi pimpinan } \\
\text { divisi audit internal, namun dipindahtugaskannya manajer } \\
\text { (kepala) divisi audit internal ke BAK membuat kinerja } \\
\text { divisi audit internal terganggu. }\end{array}$ \\
\hline & & $\begin{array}{l}\text { - Sebagian unit yang diaudit memiliki pandangan bahwa } \\
\text { auditor hanya mencari-cari kesalahan tanpa mampu } \\
\text { membuat laporan. }\end{array}$ \\
\hline 10. & Perception from auditee & $\begin{array}{l}\text { - Persepsi yang negatif dari auditee yang sedikit banyak } \\
\text { "memaksa" auditor untuk lebih banyak melakukan tugas } \\
\text { consulting dibandingkan pengawasan. }\end{array}$ \\
\hline \multirow{2}{*}{11.} & \multirow[t]{2}{*}{ Recources } & $\begin{array}{l}\text { - Tidak adanya pos anggaran khusus untuk divisi audit } \\
\text { internal dalam melakukan perencanaan dan pelaksanaan } \\
\text { audit, kecuali gaji dan reward pada satgas kemungkinan } \\
\text { mempengaruhi kinerja auditor internal. }\end{array}$ \\
\hline & & $\begin{array}{l}\text { - Selain itu tidak adanya ruang tersendiri, kemungkinan } \\
\text { mengakibatkan terganggunya aktivitas pengawasan dan } \\
\text { audit. }\end{array}$ \\
\hline
\end{tabular}

